\title{
CIAŁO LUDZKIE A ORGANIZM ZWIERZĘCIA: UJĘCIE HANSA-EDUARDA HENGSTENBERGA
}

\begin{abstract}
Streszczenie. W artykule zaprezentowano jeden z istotnych aspektów wizji cielesności zarysowanej oryginalnie w wielu odsłonach przez Hansa-Eduarda Hengstenberga, a mianowicie jej relacji do organizmu zwierzęcego. Wbrew aktualnie dominującej naturalistycznej tendencji niemiecki myśliciel ukazuje ciało człowieka jako jakościowo odmienne w stosunku do organizmu zwierzęcego, a nie tylko różniące się od niego pod względem ilościowym. Scharakteryzowano najpierw zasadę rzeczowości, która współdeterminuje ludzkie ciało i jego organy, sprawiając, że jest ono ze swej istoty zasadniczo inne niż zwierzęce. Człowiek ma ciało, a zwierzę jest tylko organizmem. Ciało to za sprawą uzdolnienia człowieka do aktów o charakterze rzeczowym (wyspecjalizowania w nich), zapodmiotowanych w duchu ludzkim, spełnia dwojakie funkcje: typowo biologiczne (właściwe dla świata zwierzęcego), a także o charakterze nieorganicznym. Cielesność ludzką należy więc rozpatrywać w sensie fizycznym oraz jako wyraz ducha. Swoje analizy na ten temat Hengstenberg rozwijał z pozycji fenomenologiczno-metafizycznych.
\end{abstract}

Słowa kluczowe: ciało; organizm; zwierzę; rzeczowość; duch; fenomenologia; metafizyka

1. Wprowadzenie. 2. Rzeczowość jako czynnik wyróżniający byt ludzki. 3. Wizja cielesności ludzkiej. 4. Dlaczego człowiek ma ciało a zwierzę to organizm? 5. Zasada jedności ludzkich funkcji a charakter aktywności zwierzęcia. 6. Specyficzna ranga ludzkiego ciała i jego organów. 7. Zakończenie.

Człowiek to jedyna istota, która ma ciało jako wyraz duchaํㅗ․

\section{WPROWADZENIE}

Współcześnie dużą popularność zyskał pogląd zwany antropomorfizmem ontologicznym (Wróblewski 2016, 86-87). Charakterystyczne dla niego jest podnoszenie rangi zwierzęcia do rangi człowieka.

1 Jest to myśl Hengstenberga, która często powraca w jego rozważaniach antropologicznych. 
Wskazuje to na zacieranie istotowej różnicy między tymi bytami. Jednocześnie w myśli współczesnej dominuje naturalistyczna tendencja w spojrzeniu na ciało ludzkie. Eliminuje ona jakościową różnicę między nim a organizmem zwierzęcym, gdyż ta rzekomo może mieć charakter jedynie ilościowy. Dlatego tak ważną sprawą jest przywoływanie tych teorii cielesności, które służą rozstrzyganiu trudności związanych z odczytaniem jej natury, charakteru i przeznaczenia. Za jedną z nich należy z pewnością uznać tę, którą zaproponował wybitny myśliciel niemiecki o orientacji fenomenologiczno-metafizycznej Hans-Eduard Hengstenberg 2 .

Celem niniejszego artykułu jest ukazanie, jak wspomniany myśliciel starał się oryginalnie uzasadnić występowanie jakościowej odmienności ciała ludzkiego (od samego początku jego egzystencji) $\mathrm{w}$ stosunku do organizmu zwierzęcego. $Z$ tego tytułu najpierw zostanie omówiona w zarysie zasada rzeczowości, która określa takie ujęcie tej problematyki przez wybitnego myśliciela. Zostanie też zaakcentowane, że Hengstenberg dowodził słuszności swojej tezy w dyskusji ze znaczącymi autorami. Rozwijał ją i przedstawił w ramach swojej fenomenologiczno-metafizycznej metody filozofowania. Na bazie fenomenologii bytu ludzkiego wykrystalizowały się metafizyczne wypowiedzi o człowieku i jego cielesności. Nie chodzi zatem, jak

2 Hans-Eduard Hengstenberg urodził się 1 września 1904 roku w Hombergu (obecnie Duisburg). Studiował w Kolonii nauki ekonomiczne, społeczne, psychologię i filozofię. Spośród jego trzech słynnych nauczycieli, którymi byli Max Scheler, Nicolai Hartmann i Helmuth Plessner, największy wpływ na wykrystalizowanie się jego fenomenologicznej metody filozofowania wywarł niewątpliwie Scheler. Po II wojnie światowej wykładał filozofię najpierw w Pedagogicznej Akademii w Oberhausen, od 1953 roku w Pedagogicznej Akademii w Bonn, a od 1961 roku jako profesor zwyczajny na uniwersytecie w Würzburgu. Po przejściu na emeryturę w 1969 roku podjął wykłady z filozofii na uniwersytecie w Salzburgu. Zmarł 8 sierpnia 1998 roku. Robert Spaemann włączył go do grona najwybitniejszych antropologów niemieckich XX wieku, do którego zwykle zalicza się Maxa Schelera, Arnolda Gehlena i Helmutha Plessnera. Zdaniem Spaemanna dzieło Philosophische Anthropologie Hengstenberga (którego nakład w pięciu wydaniach osiągnął ponad sto tysięcy egzemplarzy) jest najlepszym podręcznikiem z zakresu antropologii filozoficznej (por. Binkowski 1990, 243; Hüntelmann 1999, 283-285; 2020). 
podkreślał sam Hengstenberg, o metafizykę konstruującą pojęcia, gdyż metafizyczne pryncypium/zasada może być przyjęte/przyjęta wtedy, gdy sam fenomen tego wymaga (Hengstenberg 1975, 181). W zakończeniu artykułu zostanie zaznaczone, w czym wyraża się nowość ujęcia zagadnienia zaproponowanego w tych analizach wobec dotychczasowych interpretacji poglądów wybitnego niemieckiego fenomenologa.

\section{RZECZOWOŚĆ JAKO CZYNNIK WYRÓŻNIAJĄCY BYT LUDZKI}

Pod pojęciem rzeczowości Hengstenberg rozumie postawę, która skłania do zwrócenia się ku innemu bytowi ze względu na niego samego, a nie z uwagi na własną korzyść (Hengstenberg 1957, 9). Człowiek zachowuje się (działa) rzeczowo, kiedy obchodzi się z kimś innym w taki sposób, w jaki chciałby być przez niego potraktowany, odnosząc się doń oraz postępując z nim tak, że odpowiada to naturze tego drugiego. Jeśli zaś usiłuje go oceniać, to zawsze $\mathrm{z}$ wykluczeniem zamiaru demonstrowania własnej dominacji. W duchu takiej postawy powinni prowadzić swe badania uczeni. Filozofowi chodzi o nic innego, jak o poznanie samego bytu. Przyrodnikowi przyświeca podobna idea: pozwolić ukazać się badanemu przedmiotowi takim, jakim się jest, nawet wtedy, gdy ewentualne utylitarne spożytkowanie rezultatów badań jest nie do przewidzenia lub w ogóle nie należy się ich spodziewać (Hengstenberg 1989, 46).

Jedna z najistotniej różnicujących cech człowieka w stosunku do zwierzęcia, która fenomenologicznie jest możliwa do stwierdzenia, polega na rzeczowości (Hengstenberg 1957, 9). Zwierzę nie zachowuje się rzeczowo, ani odwrotnie - nierzeczowo. W przypadku tego stworzenia nie można jednak mówić o uchybieniu w tym względzie, ponieważ nie jest ono zdolne przyjąć postawy rzeczowej. Zwierzę dąży do pozyskania określonej rzeczy zdeterminowane uzyskaniem korzyści biologicznego rodzaju. Jednak zwierzę nie zawsze przejawia swoją aktywność tylko $z$ uwagi na tego rodzaju dobra, ma bowiem 
również „pragnienia duchowe”. Świadczy o tym na przykład przywiązanie psa do swego właściciela, który obdarza go pieszczotami, co odpowiada potrzebie życiowej czworonoga. Ponadto zwierzę nie zawsze działa ze względu na pożytek siebie jako indywiduum, gdyż czyni to często dla zachowania gatunku. Niemniej wszelkie reagowanie zwierzęcia na rzeczy i bodźce docierające $z$ otaczającego świata ma jako swój przedmiot dobra witalne (Hengstenberg 1957, 9-10).

Również zwierzęca ciekawość zorientowana jest na takie dobra albo na „pozbawione celu” penetrowanie (ujawniające tzw. pożądliwe zachowanie). Nie ma więc ona żadnego związku z rzeczowością (Hengstenberg 1957, 10). Jak zatem należy interpretować śpiew ptasi, który nie jest wykonywany z chęci samych zalotów? Otóż zarówno ten, jak i wszelkie inne ponadutylitarne akty występujące u zwierzęcia nie są oznakami rzeczowego reagowania na świat bodźców. Zachowania zwierzęcia są sensowne tylko w ograniczonym czasie, na przykład w okresie gromadzenia zapasów. Ujawniają więc charakter działania popędowego, co potwierdza, że nie wykazują jakiegokolwiek związku z rzeczowością. Naturalnie, zachowania te nie mogą mieć żadnego ponadczasowego znaczenia i treści.

Rzeczowość jest przyjazną relacją z bytem, współpracą człowieka w urzeczywistnianiu właściwej mu struktury celowej. Taka postawa wyraźnie dochodzi do głosu u tych uczonych, którzy w swoich badaniach nie są nastawieni na osiąganie zysków, a równocześnie podejmują je nie z samej tylko ciekawości.

Rzeczowości nie należy też mieszać z trzeźwą oschłością i brakiem zaangażowania - dodaje Hengstenberg (Hengstenberg 1957, 14). Taka postawa zakłada wyzucie się $\mathrm{z}$ siebie, to jest całkowite oddanie, abstrahujące od jakiegokolwiek nastawienia na własny interes. Rzeczowość nie ogranicza się zatem do aktów intelektualnych. Stąd możemy mówić o rzeczowym uczuciu lub o rzeczowym poruszeniu uczuciowym, jakim jest par excellence zachwyt jako reakcja na znakomicie wykonaną interpretację utworu muzycznego. Tym bardziej przejawem rzeczowego poruszenia uczuć jest miłość o charakterze 
osobowym, wyrażająca się w gotowości do poświęceń. Jest to najwyższe urzeczywistnienie rzeczowości. Utożsamienie jednak rzeczowości z miłością byłoby, z jednej strony, zbyt wąskim rozumieniem rzeczowej orientacji, a z drugiej strony - zbyt szerokim ujęciem osobowej miłości. Cześć, sprawiedliwość, odwaga, krótko mówiąc - wszelkie klasyczne cnoty również podpadają pod pojęcie rzeczowości.

Rzeczowość należy także odróżnić od pojęcia obiektywności. Rzeczowość zakłada obiektywność, ale nie redukuje się do niej. Rzeczowość wznosi się ponad tę postawę przez swój charakter życzliwego oddania i zaangażowania, podczas gdy sama obiektywność jest pozbawiona tego na wskroś ludzkiego (personalnego) czynnika. $\mathrm{Na}$ przykład sędzia musi być obiektywny, ale naprawdę dobrze spełnia swoją funkcję tylko wtedy, gdy okazuje się także rzeczowy. Znaczy to, że stara się z całą życzliwością i zrozumieniem wniknąć w indywidualność oskarżonego oraz w szczególne okoliczności jego czynu. Urzędnik realizujący prawo tylko obiektywnie i formalnie nie jest rzeczowy (Hengstenberg 1957, 16).

Jak usiłuję wykazać w dalszych analizach, zdolność do rzeczowości nie może pozostać bez wpływu na charakter i specyfikę ludzkiego ciała. Zdolność ta determinuje morfologię ludzkich organów oraz ciało jako całość, przez co istotnie różni się organizmu zwierzęcego (Hengstenberg 1961, 254-255). Należy je postrzegać jako wyraz ducha.

Konsekwentnie do stosowanej metody fenomenologiczno-metafizycznej Hengstenberg nie zatrzymuje się na opisie i prezentacji rzeczowości, ale docieka też jej źródła. Może nim być tylko duch (Hengstenberg 1957, 224)3. W nim bowiem i dzięki niemu mamy zdolność urzeczywistniania działań właściwych tylko człowiekowi, czyli aktów rzeczowych (Hengstenberg 1957, 135).

3 Dowiedzione zostało tu twierdzenie, iż sposób działania bytu odsłania jego naturę (por. Stępień 1995, 228). 


\section{WIZJA CIELESNOŚCI LUDZKIEJ}

Aby właściwie zrozumieć tytułową problematykę: ciało ludzkie a organizm zwierzęcia, należy najpierw zapoznać się z wizją cielesności ludzkiej u Hengstenberga. Otóż niemiecki myśliciel odróżnia cielesność w znaczeniu fizycznym w dwojakim jej pojmowaniu od cielesności jako wyrazu ducha. Tym samym jednak nie ma na myśli dwu warstw albo dwóch stron cielesności. W doczesnej egzystencji człowiek jest obdarowany tylko ciałem jako wyrazem ducha. I tego rodzaju cielesność konsekwentnie zawsze ma na myśli, gdy argumentuje, że ciało ludzkie nie jest ciałem zwierzęcym. Mówi o tym wyraźnie, gdy stwierdza: „Pojęcie ciała jako wyrazu ducha powinno być zastrzeżone dla sfery ludzkiej i nie możemy trafnie go używać w odniesieniu do wszystkiego, co spotykamy poza nią" (Hengstenberg 1955, 197).

Jednak nieco paradoksalnie Hengstenberg pokazuje, że w odniesieniu do człowieka istnieją również podstawy do mówienia o ciele $\mathrm{w}$ wymiarze fizycznym, i to w podwójnym sensie. Po pierwsze, $\mathrm{w}$ doczesnej egzystencji możemy mówić o takim ciele $\mathrm{z}$ uwagi na jego fizyczne parametry, takie jak na przykład waga, rozciągłość przestrzenna, zmienność itd. Najbardziej cielesna w tym sensie jest waga, natomiast twarz to najwyrazistsza forma manifestacji ciała jako wyrazu ducha. Twarz jednak przy określonych przeżyciach może „stwardnieć” czy skostnieć i przez to ujawniać przede wszystkim swoją fizyczną stronę (w sensie zatracenia oznak życia osobowego) ${ }^{4}$ i prezentować się niby maska. Co około siedem lat w wyniku wymiany komórek ciało człowieka w swym wymiarze fizycznym (Körper) staje się zupełnie inne - tworzy go suma innych komórek, nie dotyczy to jednak ciała jako „wyrazu ducha” - Leib (Hengstenberg 1955, 201).

4 Cielesność fizyczną Hengstenberg często opisywał metaforycznie, a wtedy należy rozumieć ją jako m.in. obniżenie stopnia witalności - oznakę martwoty. Jest to zbieżne z pojmowaniem cielesności w drugim sensie, odnoszonym do ciała już nieżyjącego (martwego). 
Drugie rozumienie naszego ciała w tym wymiarze należy odnieść do jego sytuacji bytowej po naszej śmierci. Jak wiadomo, staje się ono zwłokami, czyli ciałem martwym ${ }^{5}$.

Hengstenberg uwrażliwiał jednocześnie na tę wcale nieoczywistą (a nawet bardzo zagrożoną ${ }^{6}$ ) w mentalności współczesnego człowieka prawdę o ciele, że nie da się go ująć wyłącznie w wymiarze fizycznym, czyli przez odwołanie się do takich wskaźników, jak ciężar, miara, masa. W związku z tym nie bez krytyki odniósł się on do stosowanej praktyki lekarskiej. Jego zdaniem nasz język został tak bardzo zdeformowany wskutek zbiurokratyzowania, że przeważnie w urzędowych badaniach lekarskich nie patrzy się na ciało człowieka inaczej, niż przez pryzmat kategorii fizycznych (np. waga, miara) (Hengstenberg 1957, 272).

W dociekaniach na temat tak rozumianej cielesności Hengstenberg słusznie zauważa, że nie ogranicza się ona do świata ludzkiego, skoro jest ujmowana w parametrach fizycznych. Występuje także w świecie pozaludzkim w postaci niezliczonej ilości bytów. Ekstremalnymi jej przykładami są blok skalny i hałda piasku. Niemniej również twarz mężczyzny, jeśli jest pozbawiona wyrazu, upodabnia się do martwego obiektu (w sensie utraty obrazu cech charakteru tradycyjnie uznawanych za wyróżniające mężczyznę: hart ducha, dzielność, stanowczość) (Hengstenberg 1957, 273-274). Pozaludzkie całości podlegają pewnemu stopniowaniu w odniesieniu do tego rodzaju bytowości, począwszy od wymienionych i innych artefaktów: blatu stołu, masy płynu itd., aż po byty, u których ta cielesność ma charakter konstytucji (rośliny i zwierzęta), a nie agregacji

5 Jednak zwłoki te zasługują na szacunek, gdyż są one znakami osoby.

6 Musimy uwrażliwić się na tendencję redukowania ciała do rangi rzeczy, jaka objawia się w popularnej ideologii transhumanizmu. Według tego stanowiska nasza cielesność, jako niedoskonała, musi zostać radykalnie udoskonalona, a nawet totalnie zanegowana.

7 Jest to parafraza, gdyż Hengstenberg wyraził się na ten temat bardziej radykalnie (Hengstenberg 1955, 198). 


\section{DLACZEGO CZŁOWIEK MA CIAŁO A ZWIERZĘ TO ORGANIZM?}

Hengstenberg nigdzie w swych analizach nie definiuje pojęcia organizmu. Niemniej ich treść wskazuje jednoznacznie, że rozumie to pojęcie klasycznie. Organizm to każdy byt żywy z uwagi na zachodzące w nim procesy metaboliczne (metabolizm organiczny), a zatem jest nim par excellence zwierzę. Jak podkreśla Hengstenberg, zwierzę jest niczym innym i niczym więcej niż organizmem, gdyż nie posiada ono zasady nieorganicznej (czyli duchowej duszy) (Hengstenberg 1957, 89). Twierdząc tak (czyli, że zwierzę jest tylko organizmem), nie wyklucza, że nie ma ono doświadczeń psychicznych. Jak bowiem podkreśla, jest ono organizmem ożywionym, obdarzonym duszą zmysłową. Dlatego zwierzę reaguje na to, czego doświadcza i co napotyka w swoim otoczeniu. Doznaje lęku, cieszy się, czuje ból, cierpi, potrafi dostosować swoje zachowanie do sytuacji, w jakiej się znajduje itp. (Hengstenberg 1957, 135, 238, 330) ${ }^{8}$.

Hengstenberg nie wypowiada się natomiast na temat zdolności zwierząt do przeżyć estetycznych. Tymczasem istnieje pogląd, że zwierzęta mają zdolność do doświadczeń (przeżyć) estetycznych. Reprezentuje go, między innymi, wybitny ornitolog Richard O. Prum. Jego zdaniem zwierzęta subiektywnie postrzegają (doświadczają) cechy piękne u innych osobników lub na przykład w gniazdach czy innego rodzaju siedzibach zbudowanych przez potencjalnych partnerów seksualnych. Wybierają nosicieli takich cech (w tym budowniczych owych atrakcyjnych i bezpiecznych dla nich miejsc), przez co włączają się, acz nieświadomie, w wyścig upiększania się, aby być wybranym lub móc wybierać partnerów seksualnych. Kierują

8 Dodajmy, że u wyżej rozwiniętych zwierząt, zwanych prymatami, dostrzega się zdolność do wytwarzania narzędzi pomagających w pozyskaniu środków zaspokajających ich potrzeby witalne. Wszystko to świadczy o tym, że posiadają one życie nie tylko wegetatywne, ale i psychiczne. 
się zatem w jakiś sposób „estetyką" w instynkcie doboru płciowego (Prum 2019, 222-226).

Jeśli zatem niemiecki myśliciel używa pojęcia „organizm”, to najczęściej odnosi je do świata zwierzęcego, a następnie roślinnego. Jednocześnie niejednokrotnie mówi o organizmie ludzkim. W tym wypadku jednak ma na myśli wyłącznie sferę określaną klasycznie jako materialno-cielesna (czysto organiczna) (Krąpiec 1991, 159-166). Według Hengstenberga ona nie istnieje, gdyż pozwala się wyróżnić tylko czysto abstrakcyjnie. Człowiek ma bowiem wyłącznie ciało rozumiane jako wyraz ducha. Charakteryzuje się ono specyficzną bytowością w porównaniu do organizmu zwierzęcego.

Zdaniem niemieckiego fenomenologa specyfikę ludzkiej cielesności współokreśla rzeczowość. Jak już podkreślono, jest to postawa zwracania się (stosunek, zareagowanie) do drugiego bytu ze względu na niego samego, czyli z perspektywy tegoż bytu i z punktu widzenia jego dobra. Jest to postawa całkowicie bezinteresowna. Może ona zaznaczyć się w aktach intelektualnych, wolitywnych, emocjonalnych (Hengstenberg 1957, 223).

Dlaczego tak ważne jest uwzględnienie rzeczowości w kontekście tych analiz? Wyjaśnia to wypowiedź samego Hengstenberga: „O różnicy ciała ludzkiego jako wyrazu ducha w stosunku do organizmu zwierzęcego stanowi to, że organizm ten nie tylko nie zniósłby determinacji płynącej z zasady rzeczowości, lecz zostałby pod jej wpływem zniszczony" (Hengstenberg 1957, 224). U zwierzęcia, jak już wiadomo, nie istnieje ukierunkowanie właściwe dla postawy rzeczowej. Dlatego byłoby czymś dalece nienaturalnym i konsekwentnie do tego dalece destruktywnym zmuszanie go do tego typu reagowania?

9 Skrajnym tego przykładem jest tresura w cyrku. Hengstenberg nie odrzuca bowiem w ogóle tego typu praktyki. Natomiast z pewnością cena tresury w cyrku rzeczywiście okazuje się nazbyt wysoka. Jawi się jako okrutna praktyka, jeśli zważyć na kontekst, w jakim się ją przeprowadza. Składa się nań wymuszanie od zwierzęcia siłą określonych zachowań i przyswajania przez nie różnych sztuczek poprzez zadawanie mu bólu. Przy tresurze 
Wymiaru biologicznego człowieka nie da się zredukować do poziomu zwierzęcej biologii (stanowiącej o właściwej naturze bytowości naszych mniejszych braci). Człowiek jest bowiem istotą o specyficznych przymiotach również w swym biologicznym wymiarze (czyli materialno-cielesnym). Ciało i organy cielesne człowieka są wyspecjalizowane w zakresie rzeczowości i dzięki niej. Uzdolnienie do tej orientacji, możliwe dzięki jej zapodmiotowaniu w duchu, współdeterminuje morfologię ludzkich organów i członków oraz ciało jako całość (Hengstenberg 1961, 255). Z tego również tytułu ludzkie ciało jest w swej bytowości określone przez relację do ducha ${ }^{10}$. Nie istnieje ono autonomicznie, gdyż swą spójność czy zwartość (Geschlossenheit) ciągle uzyskuje w duchu i dzięki niemu (Hengstenberg 1957, 224).

Nie ulega więc wątpliwości, że człowiek nie jest tylko organizmem zwierzęcym, obdarzonym ponadto, jak się wyraża Hengstenberg, wzniosłą świadomością (erhebenden Berwußtsein) (Hengstenberg 1957, 88). Człowiek, powtórzmy za tym myślicielem, to byt, który ma ciało (der Leib), podczas gdy zwierzę jest tylko organizmem. Co oznacza to stwierdzenie? Odpowiedź stanie się bardziej zrozumiała, gdy uwzględnimy, czym jest zwierzęcy organizm i jak funkcjonuje. Jak zaznacza Hengstenberg, w owym organizmie poszczególnymi organami i członkami włada cielesny centralny organ ${ }^{11}$. Jest nim tylko ten, od którego wszystkie inne są najbardziej zależne (mózg) ${ }^{12}$, ale

często stosuje się ponadto swoiste praktyki stymulujące, takie jak bicie batem, rażenie prądem, wbijanie haka za uszami zwierzęcia (głównie w przypadku słonia).

10 To, że zachowuje ono swą stałość i tożsamość, mimo zachodzących w nim zmian, ma swoje istotnie metafizyczne źródło w duchu. Zresztą, zdaniem Hengstenberga, nieustannie doświadczamy takiego właśnie charakteru ciała. Dodajmy, że można o nim mówić w tym sensie, iż jest ono elementem współkonstytuującym ludzką bytowość. Istnieje bowiem jeden podmiot czynności zarówno materialno-cielesnych, jak i duchowych. Niemniej ciało nigdy nie staje się tym samym kompletną substancją, czyli bytem istniejącym w sobie, to jest na sposób podmiotu. Ciało posiada swą wysoką rangę organizacji materialnej za cenę niesamodzielności egzystencjalnej (Hengstenberg 1957, 224).

11 Organy te i członki konstytuują całość, a owa całość z kolei wyznacza im swoje miejsce i funkcje oraz specyficzny dla poszczególnych organów cel.

12 Hengstenberg wprawdzie nie twierdzi, że chodzi tu o ten organ. Jednak według jego ucznia, Rafaela Hüntelmanna, prawdopodobnie miał on na myśli właśnie mózg. 
poza tym, stosownie do swej istoty, nie odgrywa on żadnej szczególnej roli. Również dusza witalna zwierzęcia to zasada zanurzona $\mathrm{w}$ organizmie, całkowicie mu przyporządkowana. Potwierdza to tylko, że zwierzę jest na wskroś ożywionym organizmem i niczym ponadto. Zwierzę bowiem nie dysponuje (nie włada) organizmem, czyli nie jest w stanie zdobyć się na dystans wobec jego prawidłowości organicznych, a tym bardziej nie może ich przekraczać. Indywiduum zwierzęce i organizm są tym samym. W związku z tym, według Hengstenberga, Plessner słusznie mógł stwierdzić, że zwierzę jest zamknięte w sobie (Plessner 1988, 21). Pojedynczy organ nie potrafi dokonać niczego, co nie byłoby jednocześnie dokonaniem całego organizmu i jego zadaniem. Każdy organ (w tym centralny) jest w podobny sposób związany z funkcją, którą spełnia, nie mogąc się od niej zdystansować. Nie jest mu wyznaczona żadna funkcja indywidualna (solowa), która byłaby przydzielona przez nieorganiczną zasadę.

Dlaczego, w przeciwieństwie do zwierzęcia, człowiek nie jest tylko ciałem, lecz owym ciałem dysponuje? Zdaniem Hengstenberga na temat specyficznego statusu ludzkiego ciała względem zwierzęcego organizmu istotne analizy poczynił Martin Heidegger między innymi w Was heisst Denken? Wspomniał tam chociażby o różnicy między ludzką dłonią a zwierzęcymi szponami, pazurami, łapami, podkreślając, że tylko istota, która potrafi myśleć, może mieć dłoń. Heidegger jednak nie uzasadnia metafizycznie specyficznego statusu ludzkiego ciała (Hengstenberg 1961, 102-103). Nie ulega wątpliwości, że czyni to Hengstenberg. Jak bowiem podkreśla, owa zdolność dysponowania własnym ciałem wynika $\mathrm{z}$ zasady nieorganicznej ${ }^{13}$, z ,ja" osobowościowego $\left(S e l b s t^{14}\right)$, będącego manifestacją ducha i jego

13 Selbst („ja” osobowościowe), jak wynika z całości rozważań Hengstenberga, można nazwać zasadą nieorganiczną, ale chyba w szerszym znaczeniu z uwagi na to, że to „ja" osobowościowe jest „słowem” ducha i jego wyrazem. W ścisłym sensie taką zasadą jest tylko ludzki duch.

14 Wolno, jak sądzę, w ten sposób rozumieć sens tego terminu. Nie można w każdym razie tłumaczyć go jako podmiot osoby. Jak bowiem podkreśla Hengstenberg, Selbst nie jest 
stwórczym nooum (Hengstenberg 1957, 203-204). Nic więc dziwnego, że wszelkie akty owego ,ja” mają diametralnie przeciwstawny charakter względem wszystkiego, co jest ze swej natury organiczne, czyli zwierzęce. Są one bowiem dziełem naszej wolności (Hengstenberg 1957, 42). Dlatego członki i częściowo również organy człowieka mogą podjąć zadania indywidualne, które nie pochodzą z prawidłowości organicznych, lecz z rzeczowego (bezinteresownego) lub nierzeczowego zwrócenia się do drugiego bytu. Nic więc dziwnego, że niektóre członki są całkowicie „suwerenne” (freigestellt). Takim członkiem jest dłoń. Inne zaś ujawniają uzdolnienie i gotowość do spełniania zadań zarówno organicznych, jak i nieorganicznych. Na przykład płuca służą nie tylko celom wegetatywnym, ale również w sposób sprawczy wykonywaniu śpiewu, mówieniu i grze na instrumentach dętych. Oko służy refleksyjnemu widzeniu i świadomie realizowanym badaniom. Analogicznie działa ludzki mózg.

\section{ZASADA JEDNOŚCI LUDZKICH FUNKCJI A CHARAKTER AKTYWNOŚCI ZWIERZĘCIA}

Ludzkie członki i organy, niezależnie od funkcji o charakterze organicznym, mogą być wykorzystywane do spełniania specjalnych zadan, niedeterminowanych przez strukturę biologiczną. $Z$ tego tytułu zachowanie ich spójności wymaga całkiem innej zasady jedności. Jak już zaznaczono, żaden organizm zwierzęcy nie zniósłby tego, że jego części zostały wykorzystane do funkcji życiowo mu obcych (przekraczających możliwości jego natury biologicznej). Spowodowałoby to bowiem jego dezintegrację. Wprawdzie ptak „śpiewa”, chociaż nie jest to nieodzowne do czysto biologicznego celu - zalotów wobec

dane wraz z początkiem istnienia człowieka. Ono dopiero powstaje, a jego pełnia musi zostać wytworzona. Duch jest tym, który owo Selbst przenika swoją obecnością w każdej chwili, ażeby mogło pozostać ze sobą w jedności i identyczności. Selbst posiada swą stałość i tożsamość, mimo zachodzących zmian, ale to dzieje się za sprawą ducha (Hengstenberg 1957, 203). 
biologicznej partnerki. Nie wchodzi tu jednak w rachubę świadomy zamiar (intencja). W tym śpiewie nie dochodzi do głosu rzeczowe (wolne) zwrócenie się ptaka do świata ${ }^{15}$. Tak czy inaczej, zwierzę nie podejmuje swojej aktywności w sposób wolny (rzeczowy), jak to się dzieje u ludzi. Ci przecież świadomie wytężają swój umysł, jak o tym świadczą na przykład teoretyczne spekulacje, twórczość pisarska albo usprawnianie innych umiejętności intelektualnych.

Tresura nie podważa takiego postrzegania świata zwierząt, w którym nie sposób stwierdzić działań o charakterze rzeczowym. Umiejętności nabyte w jej wyniku nie są nowym rodzajem ich aktywności, gdyż oznaczają zaledwie zewnętrzne przekształcenie istniejącej zwierzęcej funkcji. Zwierzę nie podejmuje jej od wewnątrz swego jestestwa. Papuga nie mówi sama z siebie, lecz przemawia przez nią treser. O takim uzdolnieniu w świecie tych stworzeń można byłoby sądzić wtedy, gdyby dwie papugi za pomocą wyuczonych słów (tresury) zyskały zdolność komunikacji werbalnej i porozumiewały się w sposób ludzki. Koń cyrkowy nie wykonuje tańca jako nowego i właściwego sobie rodzaju działania. O takim fakcie można by mówić wtedy, gdyby konie cyrkowe same zaaranżowały wspólne tańce. Dlatego w przytoczonych i analogicznych przypadkach nie chodzi o prawdziwie dwojaką funkcję poddawanych tresurze organów. Organy te są przekształcone tylko w ich zwierzęcej, zewnętrznej funkcji bądź to na skutek ciekawości i popędu naśladownictwa (u małp lub papug), bądź psychiczno-witalnej zależności od ich ludzkiego właściciela (tresera) $\mathrm{i}$ instrumentalnego potraktowania przezeń zwierzęcia.

Natomiast organy ludzkie spełniają dwojaką funkcję. Nasuwa to myśl, że musi za tym stać typowo ludzka zasada organizacji, której nie

15 Zgodnie z antropologią Arystotelesa i św. Tomasza z Akwinu, której Hengstenberg jest zwolennikiem, intencją i postawą rzeczową może się kierować jedynie istota obdarzona duszą intelektualną. Jeżeli więc ptak śpiewa zbyt długo czy za głośno, to nie ma to charakteru rzeczowego, ponieważ ptak nie ma duszy rozumnej. 
posiada organizm zwierzęcy ${ }^{16}$. Ludzkie ciało nie jest bowiem tylko zwierzęcym organizmem, jakkolwiek wykonuje również funkcje organiczne. Podobnie jak biologiczna organizacja jako całość, tak też poszczególny członek i organ u człowieka muszą mieć właściwą sobie strukturę. Zdaniem Hengstenberga morfologiczno-biologicznie specyficzny status człowieka i jego członków w stosunku do zwierzęcia i analogicznych jego członków wykazał znakomicie Arnold Gehlen (Hengstenberg 1957, 91; Gehlen 2017, 55nn; por. Kożuchowski 2021) ${ }^{17}$. Gehlen wykazał też jasno, iż strukturę popędów i ich funkcjonowanie u człowieka charakteryzuje coś swoistego i ponadzwierzęcego. Jedynie bowiem człowiek jest świadomy swojego życia popędowego, posiadając zdolność świadomego hamowania i przesuwania potrzeb, pożądań, popędów (m.in. odczucia głodu, pożądania seksualnego, popędu rozrodczego, popędu do niszczenia wyraźnie zaznaczającego się u dziecka) (Hengstenberg 1957, 91; por. Gehlen

16 Zdaniem Hengstenberga można to wyjaśnić stosując następujące porównanie: „Przyjmijmy, że jakaś grupa pracowników jako organizacja miałaby za cel wzniesienie domów. Osoby te jednak - oprócz takiego celu - powinny w trakcie trwającego miesiące lub lata budowania być razem ze sobą, ażeby rozwiązywać socjalne problemy i przydzielić, na przykład, wznoszone domy uczestnikom tego przedsięwzięcia (analogicznie się dzieje we wspólnocie osiedlowej, której członkowie, budując domy, uwzględniają przy tym ilość godzin pracy jako miarę kolejności przydziału), co wymaga, aby ta grupa posiadała całkiem niepowtarzalną organizację. Podobnie i system (Verband) ludzkich członków i organów musi mieć własną zasadę organizacji, która istotnie różni się od zwierzęcego organizmu określanego zdaniem Hengstenberga słusznie przez Plessnera jako »zamknięta forma« (Plessner)" (Hengstenberg 1957, 91-92).

17 Jednocześnie Hengstenberg na tym etapie rozważań usiłuje zarysować specyfikę morfologiczną bytu ludzkiego, stwierdzając: „Jedynie człowiek potrafi poruszać swobodnie swe kończyny we wszystkich trzech kierunkach przestrzeni i to każdą z nich w daleko idącej mierze niezależnie od drugiej. Każda forma ruchu danego członka może zostać swobodnie podjęta przez drugiego członka. Palce dłoni potrafią względem siebie poruszać się swobodnie. Żadne zwierzę nie ma takiej swobody poruszania. Zwierzę jest w stosunku do człowieka »sztywne« (steil), jakkolwiek poszczególny członek, czy też poszczególny muskuł u tego stworzenia może mieć większą elastyczność w porównaniu do człowieka" (Hengstenberg 1957, 91). 
2017, 93) ${ }^{18}$. Hengstenberg traktuje ten pogląd jako potwierdzenie swojej tezy, zgodnie z którą człowiek potrafi w sposób wolny odkryć nowy, ponadutylitarny rodzaj aktywności i prawdziwie go przyswoić. To z kolei zakłada biologicznie specyficzną organizację własnego bytu oraz poszczególnych jego organów i członków. Jej swoistość płynie z zasady rzeczowości ${ }^{19}$.

\section{SPECYFICZNA RANGA LUDZKIEGO CIAŁA I JEGO ORGANÓW}

Ciało jako wyraz ducha (der Leib) jest czymś innym niż organizm zwierzęcy. Wyprostowana postawa, specyficzny system równowagi osi ciała, musi być postrzegana w sensie specyficznej pod względem morfologiczno-biologicznym rangi człowieka. Owszem, jak podkreśla Hengstenberg, zwykle określa się morfologię ludzkich członków i organów jako niewyspecjalizowaną ${ }^{20}$. To jednak wyrażenie nie ujmuje (nie ukazuje) od strony fenomenologicznej ich specyficznego statusu. Są one niewyspecjalizowane tylko w tym sensie, że nie zostały im przydzielone żadne biologicznie zdeterminowane zadania w relacji z otaczającym światem. Na przykład, ludzka dłoń nie jest organem chwytnym, jakim dysponuje małpa. $Z$ tego bynajmniej nie wynika brak wszelkiego wyspecjalizowania. Przeciwnie, z punktu

18 Hengstenberg powiedziałby, że wszystko, co jest popędowe, ma charakter świadomy i dlatego nie jest to tylko popęd, ale także rozum i wola.

19 Oczywiście przez przywołanie morfologii narządów i członków Hengstenberg nie miał zamiaru ukazania zasadniczej różnicy między człowiekiem a zwierzęciem. Taką intencją badawczą kierował się bowiem Gehlen. Jednak według jednogłośnego stanowiska większości współczesnych antropologów fizycznych i kulturowych nie można już zgodzić się z poglądem, że differentia specifica naszego gatunku tkwi w jego strukturze morfologicznej (por. Michalski 2017, 192).

20 Hengstenberg ma tu na myśli nie tylko stanowisko Gehlena (Gehlen 2017, 55nn), ale również Plessnera, który także wskazywał na brak wyspecjalizowania ludzkich narządów (Plessner 1988, 21). Są bowiem organy wyspecjalizowane do wykonywania określonych, jedynych czynności. Ludzkie organy są plastyczne, mogą działać w różnych kierunkach i wykonywać różne czynności 
widzenia rzeczowej funkcji niektóre członki i organy człowieka muszą być pojmowane jako w najwyższym stopniu wyspecjalizowane na przykład ludzka dłoń. Nie istnieje nic bardziej wyspecjalizowanego i uformowanego w sensie niepowtarzalnie osiągniętej celowości niż ludzka dłoń - stwierdza Hengstenberg (Hengstenberg 1957, 91). Służy ona między innymi do tego, aby wytwarzać narzędzia. $Z$ tego względu posiada wyspecjalizowanie, którego nie ma żaden organ jakiegokolwiek zwierzęcia. Dłoń nie jest narzędziem, lecz narzędziem narzędzi ${ }^{21}$, ponieważ umożliwia wytworzenie każdego $\mathrm{z}$ nich ${ }^{22}$. Powstaje więc pytanie: co jest zasadą pierwotną, niebędącą już narzędziem? Ostatecznie jest nią ludzka dłoń, bo ma moc do wykreowania wszelkich narzędzi, sama nie będąc jednym z nich. Jest ona ogniwem ludzkiego ciała. $Z$ tego względu, że nie jest narzędziem, nie jest jednostronnie wyspecjalizowana (to znaczy nie posiada wyspecjalizowania w sensie dostosowania do środowiska); przeciwnie, jako wyspecjalizowana najbardziej ze wszystkich narzędzi, umożliwia zaistnienie każdego z nich. Wraz z wyspecjalizowaniem w rzeczowości idzie w parze swoista morfologiczno-biologiczna struktura. Ludzka dłoń nie jest embrionalną, prymitywną dłonią gada lub dłonią pierwotnego lądowego kręgowca, do której został dodany duch ${ }^{23}$. Wiedzie ona w pewnym stopniu swoiste życie. Dłoń wyraża i może reprezentować całego człowieka. Zaznacza się to i ujawnia szczególnie w artystycznym tańcu i w towarzyszących mu gestach. Dłoń sama w sobie jest piękna, jakkolwiek trzeba także mówić o pięknie całego człowieka. Postrzegamy ją jako piękną nawet wtedy, gdy jest

21 Ręka nie jest narzędziem, gdyż buduje narzędzia. Nie może nim być też dlatego, że jest ona częścią człowieka, gdy tymczasem narzędzie jest zawsze czymś odrębnym, na przykład motyka. Tę zaś wytwarza ręka, dlatego jest ona narzędziem narzędzi.

22 Jednym z tych narzędzi wytwarzamy inne, na przykład kluczem do śrub montujemy rower. Klucz ten z kolei może być naprawiony młotem kowala (Hengstenberg 1957, 91-92).

23 Nie jest też, jak podkreśla Hengstenberg, prymitywnym embrionalnym organem zwierzęcym, który uzyskiwałby swą „ludzką" charakterystykę przez to, że z zewnątrz dochodząca racjonalna zasada, usługiwałaby samej sobie. To byłoby barbarzyńskim wyjaśnieniem (Hengstenberg 1957, 92). 
przedstawiana jako odłączona od tułowia. Zdaniem Hengstenberga Albrecht Dürer zapewne nie posłużyłby się ,uduchowioną dłonią gada" jako motywem. Ludzka dłoń już u nowonarodzonego dziecka ma swoje piękno i swoją osobliwość, swoistość. Jej osobliwość jest przyrodzona, a nie dopiero wytworzona w wyniku używania (posługiwania się nią). Tak samo wyspecjalizowanie w rzeczowości nie jest zdobywane dopiero w przebiegu życia, lecz człowiek uczy się tylko czynić mu zadość (urzeczywistniać jego potencjał). Specyficzna struktura paznokci, zróżnicowanie w długości palców wzajemnie do siebie dostosowanych, subtelność dotyku uzmysławiają, że byłoby czymś śmiesznym traktowanie tego jako rzeczy prymitywnej. W tej kwestii Hengstenberg podziela spostrzeżenie Martina Heideggera, zgodnie z którym ,istota dłoni nigdy nie da się określić jedynie jako cielesny chwytny organ lub wyjaśnić z takiej perspektywy. Organ chwytny posiada na przykład małpa, ale nie ma ona dłoni. Dłoń w stosunku do wszystkich pozostałych chwytnych organów: łap, pazurów, szponów wykazuje nieskończone możliwości w zakresie tworzenia, a to znaczy, że istnieje przepaść pod tym względem między nią a tymi organami. Tylko istota, która mówi, czyli myśli, może mieć dłoń i być tak twórcza” (Hengstenberg 1957, 92). Działalność dłoni jest bogatsza aniżeli zazwyczaj sądzimy. Dłoń nie tylko chwyta, naciska, popycha, ale i daje oraz przyjmuje, i to nie tylko rzeczy, lecz także inne osoby. Dłoń trzyma i niesie. Dłoń ma tak bogate znaczenie symboliczne przypuszczalnie dlatego, że sam człowiek jest znakiem. Dłonie są składane w geście modlitwy, aby człowiek mógł stanąć przed Bogiem w prostocie. Wszystko to jest właściwym dziełem. Nie da się nazwać tego, co opisujemy inaczej, niż jako „wyspecjalizowanie w rzeczowości”.

Według Hengstenberga to, co dotyczy dłoni, można również odnieść w większym lub mniejszym stopniu do innych ludzkich członków i organów. Również ludzka noga i stopa są w najwyższym stopniu wyspecjalizowane, niepowtarzalnie morfologicznie ukształtowane, ponieważ potrafimy zarówno biegać, jak i tańczyć oraz używać nóg 
do naciskania pedałów przy grze na organach, a w razie konieczności czynić dużo więcej innych rzeczy. Istnieje więc prawdziwa i również morfologicznie obfita w następstwa specjalizacja. Na pytanie, co jest zasadą tej specjalizacji, istnieje tylko jedna odpowiedź: rzeczowe zadanie/misja. Przeznaczenie do rzeczowości współokreśliło morfologię ludzkich członków i organów. To samo dotyczy całego ciała, to jest m.in. swobody dysponowania płucami w mówieniu i śpiewaniu dzięki wyprostowanej postawie. Należy dodać - kontynuuje Hengstenberg - że nie ma to nic wspólnego z prymitywizmem. Chodzi tutaj o cielesność charakterystyczną dla człowieka. Organ, którego morfologia jest współdeterminowana rzeczowością, to organ cielesny, a materialna organizacja, składająca się z wielu części rzeczowo zdeterminowanych, to właśnie ciało. W tym sensie człowiek jest jedyną istotą, która posiada ciało jako wyraz ducha (der Leib).

\section{ZAKOŃCZENIE}

Myśl Hengstenberga nie pozostała bez echa w niemieckiej refleksji filozoficznej. Biorąc jednak pod uwagę jej rangę i doniosłość, zainteresowanie, jakie budzi w kraju ojczystym tego wybitnego fenomenologa, jest nadal zbyt nikłe, co podkreślili m.in. R. Spaemann i R. Hüntelmann. Niemniej, poświęcone jej zostały analizy m.in. w książce Struktur und Freiheit Festschrift für Hans-Eduard Hengstenberg zum 85. Geburtstag (Müller 1990), będącej zbiorem referatów z sympozjum z okazji 85. rocznicy urodzin filozofa, w dwóch doktoratach, kilkudziesięciu (około trzydziestu) artykułach naukowych. Pierwszy doktorat, P. Kunzmann, Vorentscheidung als personale Initiative, dotyczy jednego $\mathrm{z}$ ważniejszych w antropologii Hengstenberga zagadnień, a mianowicie pierwotnej decyzji człowieka ściśle związanej z problematyką rzeczowości i nierzeczowości oraz sumienia (Kunzmann 1993). W drugim doktoracie, Martin Hähnel, Das Ethos der Ethik: Zur Anthropologie der Tugend (Hähnel 2015), autor usiłuje odpowiedzieć na pytanie, jak może zostać przezwyciężony rozdźwięk 
między etyką jako refleksją nad moralnością i etosem, czyli moralnym działaniem jako takim. W swojej odpowiedzi odwołuje się do postawy rzeczowości, której antropologiczne źródła zostały wskazane wcześniej przez Maxa Schelera, Helmutha Plessnera i Arnolda Gehlena. Zarówno we wspomnianej księdze pamiątkowej, jak i w artykułach, skupiono się przede wszystkim na zarysowaniu ogólnej charakterystyki twórczości Hengstenberga i w pewnym stopniu jego teorii konstytucji oraz metody filozofowania (Hüntelmann 1999; Scherer 1990; 1992; Weier 1969; Binkowski 1949) (najwięcej analiz tego typu zaprezentował ostatni uczeń Hengstenberga, R. Hüntelmann, m.in. w Im Memoriam, Hans-Eduard Hengstenberg oraz Hans-Eduard Hengstenberg - ein fast vergessener christlichen Philosophie) (Hüntelmann 1999; 2020).

W Polsce autorem cennych analiz na temat twórczości niemieckiego myśliciela jest Piotr Pasterczyk, między innymi przez próbę prezentacji całościowego jego dorobku oraz dociekania $\mathrm{z}$ zakresu problematyki osoby, rzeczowości, metody (Pasterczyk 2003; 2013).

Problematyka podjęta w tym artykule nie była rozwijana w dotychczasowych dostępnych opracowaniach. Zwrócono uwagę, ale raczej zdawkowo, jedynie na kwestię cielesności w jej sensie fizycznym i jako wyrazu ducha. Nie podnoszono zagadnienia relacji między cielesnością człowieka a organizmem zwierzęcia, czyli tego aspektu twórczości Hengstenberga, który stanowi przedmiot niniejszych rozważań. Wprawdzie tej tematyki dotknął Zbiniew Pańpuch (Pańpuch 2015), ale autor artykułu zasadniczo przedstawia inne jej treści i aspekty.

Na zakończenie tych rozważań warto jeszcze zwrócić uwagę na dwie sprawy. Po pierwsze na to, w jaki sposób Hengstenberg odniósł się do zarzutu ze strony naturalizmu, wedle którego analizy wybitnego fenomenologa nie mają związku z ludzką biologią, ponieważ funkcjonowanie cielesności ludzkiej i jej organów wyjaśnia on przez przywołanie ponadbiologicznej zasady (duszy rozumnej). Niemiecki myśliciel nie bez racji zauważa w tym zarzucie błąd petitio principii. 
Polega on na nieuprawnionym i niemożliwym do udowodnienia założeniu (przyjmowanym z góry), że ludzka biologia da się wyjaśnić w kategoriach biologii zwierzęcej ${ }^{24}$. Jest „dogmatem” pogląd, że ludzka biologia, podobnie jak i zwierzęca, jest zamkniętą w sobie całością, której struktura wyklucza, aby owa całość mogła być determinowana przez czynnik pozabiologiczny. Ten naukowo-teoretyczny punkt widzenia jest dowolny i sprzeciwia się fenomenologicznemu stanowi rzeczy. Nie mamy w człowieku zwierzęcej biologii, nad którą byłaby dodatkowo nadbudowana metabiologiczna zasada, lecz mamy specyficznie ludzką biologię, która posiada swoją swoistość z uwagi na relację do sfery ponadbiologicznej (dusza intelektualna) (Hengstenberg 1957, 93).

Druga sprawa dotyczy wskazania możliwości kontynuowania dalszych badań problematyki cielesności ludzkiej w ujęciu omawianego autora. Problematykę tę zarysował on w swoich pismach obszernie, interesująco i wnikliwie. Dlatego treści w nich ukazane mogą stać się przedmiotem kolejnych dociekań i to w wielu aspektach. Można na przykład naświetlić cielesność w perspektywie jej ostatecznego przemienienia, spełnienia, uduchowienia, w relacji do ducha, osoby, jaźni. Warto byłoby też porównać to oryginalne ujęcie z koncepcjami cielesności u niektórych innych wybitnych filozofów niemieckich, takich jak Max Scheler czy Robert Spaemanna, a także odnieść do dociekań o ciele żyjącego jeszcze przedstawiciela fenomenologii Hermanna Schmitza ${ }^{25}$ i innych reprezentantów tego nurtu

24 W strategii redukcjonistycznej, a w tym przypadku naturalistycznej, najpierw przyjmuje się z góry założenie, że ludzka biologia jest taka sama, jak biologia zwierzęca, a następnie biologię ludzką wyjaśnia się w kategoriach i w perspektywie zwierzęcej. Krótko mówiąc, argumentuje się tak samo, jak się przyjęło, oraz nie wychodzi się poza założenie, wskutek czego nie mówi nic nowego ponad to, co zostało powiedziane w przesłance. Dowodzi się tego samego przez to samo. W tym sensie jest to błędne koło we wnioskowaniach. Inaczej mówiąc, błąd ten polega na tym, że w założeniu tkwi wniosek, czyli wszystko jest w założeniu i nic więcej nie może być we wniosku. W rezultacie nie ma postępu wiedzy.

25 Traktuje na ten temat m. in. w książce Der Leib, opublikowanej w Berlinie w 2011 roku (Schmitz 2011). 
z uniwersytetu w Kilonii, dla których tematyka cielesności stanowi centralny przedmiot badań.

\section{BIBLIOGRAFIA}

Binkowski, J. (1949). Christliche Philosphie der Existenz. Zu Hengstenbergs Philosophia Trinitatis. Wissenschaft und Weisheit, 12, 176-183.

Binkowski, J. (1990). Hans-Eduard Hengstenberg. W: E. Coreth, W.M. Neidl, G. Pfligersdorfer (red.), Christliche Philosophie im katholischen Denken des 19 und 20 Jahrbunderts, Bd. 3, 243-248. Wien - Köln: Styria.

Gehlen, A. (2017). Cztowiek jego natura i stanowisko w świecie. Toruń: Wydawnictwo Naukowe UMK.

Hähnel, M. (2015). Das Ethos der Ethik: Zur Anthropologie der Tugend. Trier: Springer VS.

Hengstenberg, H.E. (1955). Der Leib und die Letzten Dingen. Regensburg: Pustet.

Hengstenberg, H.E. (1957). Philosophische Anthropologie. Stuttgart: Kohlhammer Verlag.

Hengstenberg, H.E. (1961). Freiheit und Seinsordnung. Stuttgart: Kohlhammer Verlag.

Hengstenberg, H.E. (1975). Hans-Eduard Hengstenberg. W: L.J. Pongratz (red.), Philosophie in Selbstdarstellung, Band 1, 120-193. Hamburg: Felix Meiner Verlag. Hengstenberg, H.E. (1989). Grundlegung der Ethik. Würzburg: Verlag Dr. Johannes Königshausen.

Hüntelmann, R. (1999). Existenz, Konstitution und Modalität. Zur triadischen Konstitutionslehre. Hans-Eduard Hengstenbergs und ibren Konsequenzen für die ontologische Modaltheorie. W: E. Schadel, U. Voigt (red.), Aktive Gelassenheit. Festschrift zum 70. Geburtstag von Heinrich Beck, 203-218. Frankfurt am Main - Bern - New York - Paris: Peter Lang Verlag.

Hüntelmann, R. (1999). Im Memoriam, Hans-Eduard Hengstenberg. Philosopbisches Jahrbuch, 106, 283-286.

Hüntelmann, R. (2020). Hans-Eduard Hengstenberg-ein fast vergessener christlichen Philosophie [maszynopis przekazany przez R. Hüntelmanna w lipcu 2020 roku do dyspozycji autora artykułu].

Kożuchowski, J. (2021). Czy człowiek jest istotą z brakami? Polemika Hansa-Eduarda Hengstenberga z Arnholdem Gehlenem. Sensus Historiae, 42(1), 75-88.

Krąpiec, M.A. (1991). Ja-cztowiek. Lublin: Redakcja Wydawnictw KUL.

Kunzmann, P. (1993). Vorentscheidung als personale Initiative. Bamberg: Verlag Röll. 
Michalski, R. (2013). Homo Defectus w kulturze póznej nowoczesności. Toruń: Wydawnictwo Naukowe UMK.

Müller, G. (red.). (1990). Struktur und Freibeit Festschrift für Hans-Eduard Hengstenberg zum 85. Geburtstag. Würzburg: Königshausen u. Neumann.

Pańpuch, Z. (2015). Spór o cielesność. Lublin: Polskie Towarzystwo Tomasza z Akwinu - Wydawnictwo KUL.

Pasterczyk, P. (2003). Hengstenberg Hans-Eduard. W: A. Maryniarczyk i in. (red.), Powszechna Encyklopedia Filozofii, t. 4, 332-334. Lublin: Polskie Towarzystwo Tomasza z Akwinu.

Pasterczyk, P. (2013). Pojęcie osoby w antropologii Hansa-Eduarda Hengstenberga. Roczniki Filozoficzne, 61(4), 5-18.

Plessner, H. (1988). Pytanie o conditio humana. Warszawa: Państwowy Instytutu Wydawniczy.

Prum, R.O. (2019). Ewolucja piękna. Jak darwinowska teoria wyboru partnera ksztattuje świat zwierząt i nas samych. Kraków: Copernicus Center Press.

Scherer, G. (1990). Ontologische Konstitution bei Hans-Eduard Hengstenberg. W: V.G. Müller (red.), Struktur und Freiheit, 167-184. Würzburg: Königshausen und Neumann.

Scherer, G. (1992). Aktuelle Perspektiven im Denken Hans Eduard Hengstenbergs. Philosophisches Jahrbuch, 99, 380-397.

Schmitz, H. (2011). Der Leib. Berlin: De Gruyter.

Spaemann, R. (2001). Osoby O różnicy między czymś a kimś. Warszawa: Oficyna Naukowa.

Stępień, A.B. (1995). Wstęp do filozofii. Lublin: Towarzystwo Naukowe KUL.

Weier, W. (1969). Wege einer metaphysichen Phänomenologie. Freiburger Zeitschrift für Philosophie und Theologie, 16, 388-427.

Wróblewski, Z. (2016). Umysły zwierząt: między naiwnym antropomorfizmem a dogmatycznym antroponegacjonizmem. Zoophilogica. Polish Journal of Animals Studies, 2, 83-96.

\section{THE HUMAN BODY AND THE ANIMAL ORGANISM: HANS-EDUARD HENGSTENBERG'S ACCOUNT}

Abstract. Theis article considers an important aspects of the account of corporeality originally outlined by Hans-Eduard Hengstenberg, namely its relation to the animal organism. Contrary to the currently dominant naturalistic tendency, the German thinker shows the human body as not only quantitatively but also qualitatively different from the animal organism. To this end, Hengstenberg employs the principle of objectivity, which 
co-determines the human body and its organs and makes them essentially different from their animal counterparts. Man has a body whereas the animal is just an organism. Due to man's specific ability to perform acts of a factual nature, the human spirit enables the body to perform two functions: biological (common to the animal world) and of an inorganic type. Human flesh should be considered in the physical sense and as an expression of the spirit. Hengstenberg developed his account on this issue from both a phenomenological and a metaphysical standpoint.

Keywords: body; organism; animal; objectivity; spirit; phenomenology; metaphysics

JÓZEF KOŻUCHOWSKI

Wyższe Seminarium Duchowne Diecezji Elbląskiej

(The Major Seminary of the Elbląg Diocese in Elbląg, Poland)

Wyższa Szkoła Społeczno-Ekonomiczna w Gdańsku

(The Higher School of Social and Economics in Gdańsk, Poland)

ORCID https://orcid.org/0000-0001-6769-1473

jozefkozuchowski@gmail.com

DOI 10.21697/spch.2021.57.A.13

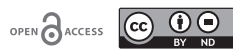

Tekst jest udostępniany na zasadach licencji Creative Commons (CC BY-ND 4.0 Międzynarodowe).

Zgłoszono: 14/07/2021. Zrecenzowano: 22/09/2021. Zaakceptowano do publikacji: 12/11/2021. 